\title{
Leaving Hinduism
}

\author{
Clemens Cavallin
}

\section{Introduction}

To know whether you have left a country or not, it is essential to know where the border is. Such a demarcation of territory is contingent in the sense that the demarcation could have been drawn elsewhere; and probably has been. Sometimes, the borders are first drawn on a map to create the country in question and then are implemented later. Sometimes, however, the boundaries grow organically through centuries of warfare and cultural negotiations and follow the natural terrain of rivers and mountains.

The notion of Hinduism as a world religion has both this artificial, neat character and the fuzzy boundaries resulting from the accumulation of religious ideas, practices, and cultural traits over millennia. As Knut Jacobsen remarks in his introduction to Brill's Encyclopedia of Hinduism, Hinduism "does not refer to a homogeneous religious tradition but a conglomerate of rituals, religious narratives, art, music, institutions, traditions, theologies, artefacts, and activities" (Jacobsen 2013). Therefore, leaving "Hinduism" is both easy and exceedingly challenging.

Adding to the difficulty of locating the borders of Hinduism — of knowing when one has actually left it behind - the modern notion of Hinduism is closely bound up with British India, from its inception in the seventeenth century up to its 1948 division into the dominions of Pakistan and India (Gottschalk 2012: Ch. 5). The partition of British India in accordance with the socalled two nation theory-which held that Indian Muslims constituted a separate nation-led to massive amounts of people crossing the border to be on the "right" side of the religious divide and to clashes in which eighteen million people were displaced and several hundred thousand, if not a million, died (Talbot 2008: 420). That is, religious identity became connected to a physical border, which, when drawn, forced those on the ground to align themselves accordingly. With over ninety percent of all Hindus living in India (in 2010, 94\%, Hackett 2015), this territorialisation of Hindu identity is a crucial point in discussions of contemporary Hinduism. As Leela Fernandes remarks, 
...both the secular state and the Hindu nationalist movement attempt to enforce a model of religion that takes the form of a fixed territory where changes in religious membership that would involve a movement between religions is restricted or severely curtailed.

FERNANDES 2011: 111

According to such an integral connection between religion and territory, leaving Hinduism for religions such as Islam or Christianity undermines one's Indian citizenship, while Buddhism, Jainism and Sikhism are Hindu; that is, they have their origin within the Indian subcontinent.

This understanding of being Hindu is even enshrined in article 25 of the Indian Constitution:

The reference to Hindus shall be construed as including a reference to persons professing the Sikh, Jaina or Buddhist religion, and the reference to Hindu religious institutions shall be construed accordingly. ${ }^{1}$

It is, therefore, in the interest of the state to make it as hard as possible to leave the religious identity that is connected to nationhood. For this purpose, many Indian states have introduced special laws, the so-called Freedom of Religion Bills, criminalising conversions that are induced through force or fraudulent means (Richards 2017: 156-277). However, this is not only a recent phenomenon, as such laws were already in place in some princely states before independence (Jenkins 2008: 113).

Such an ethno-nationalist understanding of religious identity sees religion as part of an integrated whole and considers religious conversion as a form of ethno-apostasy (Phillips and Kelner 2006) or de-nationalisation (Jaffrelot 2011b: 155), affecting culture and social belonging. It is thus important to keep in mind that "Hinduism is not a voluntary association like Christian churches are, with members and non-members. Rather, people are born Hindu; leaving Hinduism is quite difficult" (Spinner-Halev 2005: 36; see also Barua 2015).

In the following discussion, I will focus on the modern period, as the anxiety of people leaving Hinduism has, naturally, grown in tandem with the emergence and consolidation of the notion Hinduism itself during the nineteenth century and with the introduction of a nationwide census (Jaffrelot 2011b:146);

1 Part III. Fundamental Rights. Art. 25. Explanation II. At India.gov.in, National Portal of India, "Constitution of India," https://www.india.gov.in/sites/upload_files/npi/files/coi_part_full .pdf. Accessed 10/10/2017. 
for example, a discussion of leaving Vedic religion in the middle of the first millennium $\mathrm{BCE}$ would require quite a different set of parameters.

Obviously, in a discussion of leaving Hinduism, there are many important notions that can be highlighted, some of which are highly contested, but here we can only cursorily treat those of extra interest for this chapter. In addition, the most crucial of these notions is, of course, the word Hindu, which is of Persian origin. The word first denoted the people living in the area of the Indus River, which flows from north to south through present-day Pakistan. With the increasing presence of Islam in the Indian subcontinent from the eighth century $\mathrm{CE}$, it also came to refer to the religious beliefs and practices of the non-Muslim peoples living to the east of the Indus. However, the derivative, Hinduism or Hindooism, was coined only towards the end of the eighteenth century to refer to the religion of the Hindus. It was, for example, prominently used by Hindu reformer Rammohan Roy in 1816 (Lorenzen 2006: 3).

Towards the end of the same century, the fear of Hindus decreasing in their own homeland due to Christian missions and higher Muslim birth-rates led to the creation of the Śuddhi (shuddhi) ritual. Śuddhi literally means "purification" and was used by the organisation Arya Samaj for (re)convertingmainly-Muslims and Christians to Hinduism. Recently, reconversion rituals have been organised as part of Ghar Wapsis - literally "homecoming" - that is, campaigns by Hindu nationalist organisations in which Muslims and Christians (re)convert to Hinduism. A central anxiety in the discussion of leaving Hinduism and conversion centres around the question of caste $(j \bar{a} t i)$ - that is, the many thousands of endogamous groups that make up Hindu society. Jāti needs to be differentiated from the varnas, the four social classes already mentioned in the Vedic scriptures: priests, warriors and rulers, merchants and agriculturists, and, finally, servants. Those belonging to castes outside of the varna system were previously called untouchables, as they were considered ritually unclean and hence untouchable by those belonging to higher castes. The word preferred at present is Dalit (oppressed), who make up at least sixteen percent of the Indian population (approximately two hundred million people). The legal term is scheduled castes, and individuals belonging to such castes are eligible for specific positive discrimination that is provided by the government.

The concept of an apostate within Hinduism is, in one sense, not clearly connected to orthodoxy, or right faith, as the range of accepted viewpoints on any question, even that of the ultimate makeup of the universe or the nature 
of the godhead, is broad indeed. However, the conceptual pair of asstika and $n \bar{a} s t i k a$ - that is, those who affirm and those who deny-separates the Hindu orthodox from the heterodox, mainly in their respective affirmation or denial of the Vedic scriptures. Therefore, Buddhism is nāstika-not based on its denial of an ultimate creator God but due to its rejection of the Vedas and, with it, the priestly class in charge of its safekeeping, the Brahmins (Aklujkar 2014). However, for many modern Hindu nationalists, the notion of Hindu also embraces Buddhists, as the focus is not on religious doctrine and revelation but on national identity.

To apply the notion of Hinduism to the religious beliefs and practices of the Vedic period (roughly 1500 to $500 \mathrm{BCE}$ ) is misleading. It was only during the beginning of the first millennium CE that the classical form of Hinduism (or Brahmanism, Bronkhorst 2017) emerged. In the early Vedic period, for example, the later central beliefs of reincarnation and liberation had not yet been formulated. These developed in the later Vedic period within so-called śramana movements - that is, individuals and bands of ascetics and meditation practitioners seeking liberation from the bondage of the material world (Olivelle 2005). Of these movements, two proved vital enough to become long-lived religions of their own-namely, Buddhism and Jainism. When the Mauryan emperor, Ashoka (who ruled over most of the territory now belonging to modern India and Pakistan), converted to Buddhism in 263-26o вСЕ, Buddhism received support from the first "Indian" state (Bhandarkar 1957: 24).

The śramana challenge to the Vedic religion concerned the rejection of Vedic scriptures, animal sacrifices, the caste ideology, and the pre-eminence of the Brahmins, who responded by incorporating the ideology of the renouncers within a society-affirming framework that had a focus on social duty-that is, dharma. Second, they emphasised the notion of a supreme God, towards which devotion (bhakti) in the form of a temple cult was the proper attitude (though such devotion was also due to minor gods). Eventually, Buddhism was reabsorbed into its Hindu matrix, while Jainism continued to exist as a minor religious tradition.

The next major trial of the Hindu religious traditions began when Muslim armies arrived in the Indian subcontinent in the eighth century, and when, from the twelfth century on, they established their rule over northern - and later southern-India. A radical and sometimes profitable way of leaving the Hindu dharma (that is, religion and social duties) became available in this way 
(Robinson 2007b). Even when in power, Buddhists had shared basic religious and social assumptions with Hindus. Islam, on the other hand, was a clearly different and, occasionally, more intolerant religious and political alternative. One exception was the Moghul emperor, Akbar (1542-1605), who abolished the special poll tax for non-Muslims and even constructed a new syncretistic faith for his Indian empire (Kulke and Rothermund 1998: 147).

During the Moghul Empire (1526-1857), another potential avenue for leaving Hinduism grew in strength: Christianity. The religion began in India in earnest after the arrival of the Portuguese (1498) and the introduction of Catholic Christianity in Goa and other coastal areas from the sixteenth century on (Robinson 2007b). Though Syrian Christians had already arrived in the first century CE, they never achieved political control, and their converts were well integrated into the social and cultural conditions of southern India (Robinson 2003: 39-41). The Portuguese, on the other hand, used their power for active missions in their territories. These were never very large, and the more substantial Christian challenge came with the growth of British India in the nineteenth century, which brought with it a combination of protestant Christianity and modernity, prompting a Hindu reaction and, finally, a struggle for independence.

Christians, however, never managed to convert Hindus in the numbers that Muslims did. At present, only two to three percent of the population in the Republic of India is Christian (approximately 24 million persons). ${ }^{2}$

With the growth of a Hindu diaspora, beginning in the nineteenth century, another concern about leaving Hinduism emerged; namely, that of maintaining the culture, religion and ethnic identity of one's home country or region while living far from South Asia (Vertovec 2000: 102f). The crucial question is, once again, the relation of Hindu religious traditions to territory, though not all Hindus come from India; for example, in Norway and Germany, the majority of Hindus are from Sri Lanka (Jacobsen 2004: 159; Luchesi 2004).

With Western converts to and subsequent reverts from Hinduism, the basic issues are obviously different. Such acts of leaving Hinduism have mostly been treated as part of the controversies surrounding new religious movements; for example, ISKCON (the International Society of Krishna Consciousness movement) founded in New York in 1966. Converts entered into small alternative religious groups in which contact with surrounding societies was minimised. To then leave, to revert or move on to another spiritual path, could be a painful,

2 In the census of 2001, the percentage was 2.3, http://censusindia.gov.in/Census_And_You/ religion.aspx, accessed 11/10/2017. 
even traumatic experience, as seen, for example, in the following personal account of a witness:

It's hard to imagine an experience more wrenching, more potentially disorienting, than leaving a spiritual community or tradition to which one has devoted years of one's life. To lose faith in a comprehensive system of ideas that have shaped one's consciousness and guided one's actions, to leave a community that has constituted one's social world and defined one's social identity, to renounce a way of life that is an entire mode of being, is an experience of momentous implications.

GELBERG 1998

Interestingly, however, in the United States, ISKCON has changed since the 1990 due to the increasing presence and membership of diaspora Hindus. The movement's major task is now, therefore, to gain conversions to Krishna Consciousness from, "educated professional Indians rather than white counterculture 'seekers”" (Berg and Kniss 2008).

\section{$4 \quad$ Major Controversies}

Even more problematic, from a Hindu standpoint, than individual conversions is proselytisation - that is, the active seeking of converts, which, in India, is mostly done by Christian and Muslim groups (see, for example, Bauman 2014). Hindu nationalists consider proselytisation not only an attack on the Hindu religion but also an attack on the Indian nation (Misra 2011: 372f; Sarkar 2007; Richards 2004: 90).

Traditionally, one could not convert to Hinduism, but in the nineteenth century, śuddhi - a ritual for returning to Hinduism — was crafted by the revivalist organisation, Arya Samaj (Jaffrelot 2011b; Sikand 2007). The ritual is, however, controversial in the case of some tribal groups, who, before becoming Christians, were animists with no Brahmin priests, castes or worship of the main Hindu gods (Jaffrelot 2011a: 205f). The Arya Samaj version of Hinduism was that of a modern reform movement denouncing mainstream Hinduism, with its worship of idols in temples, pilgrimages and traditional understanding of castes.

In recent years, Hindu nationalist organisations, such as the Hindutva organisations Rss (Rashtriya Swayamsevak Sangh) and VHP (Vishwa Hindu Parishad), have staged such (re)conversions as part of larger programmes, so-called Ghar Wapsi (homecomings), in which thousands of Christians and 
Muslims return to Hinduism (Vandevelde 2011). These are the source of intense controversy and sometimes scandal, as in 2014, when a Ghar Wapsi campaign claimed that it had converted over fifty Muslim families to Hinduism even though a commission later concluded that the Hindu nationalist group had tricked the families with promises of houses and ration cards and that the families remained Muslim (Mishral 2015).

Underlying the controversies of conversion in India is the tension between religion as a social belonging and the principle of individual choice and freedom, which influenced the Indian constitution and its secular profile, in contrast to Pakistan, which was founded on the idea of religion as the basic criteria of nationhood (Verma 2017).

In India, the traditional system of social classification is that of caste, and it is therefore natural for a caste group to change religion as a community, or at least as families. A freely choosing individual is not the principal unit. In its struggles with the pernicious aspects of the caste system, such as untouchability and discrimination, India has instituted large-scale programmes of affirmative action towards castes classified as Scheduled Castes and Other Backward Classes (Jodhka 2012: 13of). However, the state only recognises castes within Hinduism, Buddhism, and Sikhism, which means that if someone-or a whole caste group-leaves Hinduism for either Islam or Christianity, he or she loses the right to be included in programmes of affirmative action such as quotas of government jobs or access to higher education and, at the same time, their social situation does not improve (Stephens 2007). However, there is also discrimination based on caste in Christian churches and among Indian Muslims (Waughray 2010: 347). The Indian state acknowledges caste identity among Buddhists, although Buddhism does not recognise caste (Samarendra 2016).

The recognition of caste is a sensitive topic, as being a Dalit is, of course, a strong incentive to leave Hinduism because in doing so, one thereby escapes one's oppressed position in the caste hierarchy. As a result, Hindu organisations and movements have considered a reform of the caste system to be a vital issue for over a hundred years now (Dwivedi 2012: 118f). Nevertheless, it has proven difficult to change the basic structure of caste ideology; the most favoured approach has, therefore, been not to abandon caste altogether but to introduce meritocratic principles. This approach constitutes a fundamental challenge to caste as a category based on endogamy and to the rules restricting contact across caste boundaries. To move caste towards the notion of occupation and to encourage intermarriage is, in a sense, to abolish caste itself (Ahuja 2015).

Another factor complicating the issue of leaving Hinduism is that there is not a uniform civil law code in India but rather a division of personal law 
along religious lines (Hindu, Muslim and Christian). From a legal point of view, the notion "Hindu" covers Jains, Sikhs and Buddhists; leaving Hinduism and ceasing to be Hindu is thus not the same thing. On the other hand, becoming Muslim, for example, means that one enters a new legal framework regarding issues such as inheritance and divorce (Ghosh 2009).

\section{$5 \quad$ Major Controversies and Significant Case Studies}

Interestingly, ecumenically oriented figures such as Mahatma Mohandas Gandhi (1869-1948) saw conversion in a bad light. To him, all religions were fundamentally equal and true but were interpreted by imperfect human beings (Sharma 2014). Hindus should, therefore, remain in their native religion and try to become better Hindus, not leave for another religion, which he considered socially destructive (Fernandes 2011: 117):

After long study and experience, I have come to the conclusion that (i) all religions are true; (ii) all religions have some error in them; (iii) all religions are almost as dear to me as my own Hinduism, in as much as all human beings should be as dear to one as one's close relatives. My own veneration for other faiths is the same as that for my own faith; therefore no thought of conversion is possible.

Quoted in DABHOLKAR 1992: 23

However, this stance was complicated by the question of caste and the limits of reform. To what degree was the caste system an integral part of the Hindu religion? How much could it be reformed? And why not leave for another more egalitarian religion if reform should prove unfeasible?

Gandhi did not want to abolish the principles of caste but preferred the Vedic model of four basic social classes, the varnas. He wrote:

Hinduism does not believe in caste. I would obliterate it at once. But I believe in varnadharma, which is the law of life. I believe that some people are born to teach and some to defend and some to engage in trade and agriculture and some to do manual labour, so much so that these occupations become hereditary.

Quoted in FERNANDES 2011: 116

Dalits, or harijans (children of God), as Gandhi called them, were outside the four varnas and considered ritually unclean and thus untouchable. Gandhi 
wanted to end all discrimination of the Dalits, but he did not want to abolish the system that tied specific occupations to certain groups. In the case of the Dalits, these were the most unclean and despised of professions. He also thought, according to Leela Fernandes, that "lower-caste Indians did not have the capacity to make autonomous religious decisions and were in effect being duped by missionaries into converting" (Fernandez 2010:118).

Another leader of the struggle for Indian independence, Bhimrao Ambedkar (1891-1956), held the opposite view (Coward 2003). Being himself a Dalit but having studied abroad and completed one Ph.D. at Columbia University and another one at the London School of Economics, he argued for the total abolishment of castes, including varnas, and their connection with specific occupations. In a speech that he never had the opportunity to give, he maintained that Gandhi's cultivation of goodwill towards Dalits was of no value; to strike at the root of the system, intermarriage must be practised, though it was unlikely to succeed (Ambedkar 1936). At that time, his critique of the social injustices of Hinduism had become so radical that the same year he decided to leave his native religion. Twenty years later, in 1956, and two months before his death, Ambedkar made real his decision and converted to Buddhism at a mass rally with several hundred thousand Dalits joining him (Tartakov 2007: 192). In this way, he founded a new form of Buddhism called Navayana, which counts several millions of adherents today (Zelliot 2015).

\section{6}

\section{Major Texts}

In 1923, while imprisoned on the Andaman Islands, Vinayak Damodar Savarkar wrote Hindutva: Who is a Hindu? For him, the essence of Hindu-ness was intimately connected to the territory of India; Hindus were those who thought of (and loved) India as the land of their ancestors and the place where their religion was born. This meant that all religions having their origin on the Indian subcontinent were Hindu. Together, they were part of a Hindu civilisation ("a common culture"). However, to be Hindu, Indian ancestry was also essential; that is, "having common blood," in this way forming a Hindu race (regulated by the caste system, Savarkar 1969 [1923]: 85) and a nation requiring a Hindu state. According to Savarkar, to leave Hinduism for a "foreign" religion (for example, Islam or Christianity) would thus be to reject one's nation. Indian Muslims may have Indian ancestry and love India as their fatherland, but

...they cannot be called Hindus in the sense in which that term is actually understood, because, we Hindus are bound together not only by 
the tie of the love we bear to a common fatherland and by the common blood [...] but also by the tie of the common homage we pay to our great civilization-our Hindu culture, which could not be better rendered than by the word Sanskriti...

SAVARKAR 1969 [1923]: 91f. See also SAVARKAR 1969 [1923]:10of

On the other hand, Western converts to Hinduism also failed to become Hindus even if they loved India and embraced its Sanskrit culture because, according to Savarkar's understanding, they lacked the common blood.

The "Annihilation of Caste" was a speech by Ambedkar, which he never delivered because of its strong criticism of Hinduism; it was instead published in 1936. In it, Ambedkar claimed that conversion to Hinduism was impossible because of the organisation of Hindu society into castes and that the only way to end caste discrimination was to destroy such a religion of law and oppression.

And I say there is nothing irreligious in working for the destruction of such a religion. Indeed I hold that it is your bounden duty to tear off the mask, to remove the misrepresentation that is caused by misnaming this law as religion. This is an essential step for you. Once you clear the minds of the people of this misconception and enable them to realise that what they are told is religion is not religion, but that it is really law, you will be in a position to urge its amendment or abolition.

AMBEDKAR 2014 [1936]: 307

Instead, he put forward a modern ideal in which nothing was stable except the values of liberty, equality and fraternity, which he later made part of his new form of Buddhism (to which he converted shortly before his death in 1956).

\section{$7 \quad$ Key Figures}

Dayananda Sarasvati (1824-1883) was a nineteenth century reformer of Hinduism who wanted to go back to a form of Vedic monotheism and therefore rejected medieval Hindu beliefs and practices such as temple worship, the mythologies of the great Hindu gods and pilgrimages. In 1875, he established the organisation Arya Samaj for this purpose. He also introduced the idea of śuddhi - that is, (re)conversion of people to Hinduism, and he was active in creating a unified Hindu identity through, for example, cow-protection campaigns and arguing for the use of Hindi as an official language (Datta 2012). 
Mahatma Mohandas Gandhi (1869-1948) was an Indian lawyer, trained in Britain, who took up work in South Africa before coming to India and becoming one of the central figures in the fight for independence. He was assassinated in 1948 by Nathuram Godse, a Hindu nationalist, because of his work towards reconciliation between Hindus and Muslims. For Gandhi, conversion was unnecessary because religions were equal roads to the same goal. Hindus should, therefore, work to uplift of those on the lowest rungs of the caste hierarchy, not leave their religion.

Bhimrao Ramji Ambedkar (1891-1956) came from an untouchable caste and fought throughout his whole life for the civil rights of Dalits. In 1947, he became the first law minister of the independent India and chairman for the drafting of the Indian constitution. In 1956, shortly before his death, he converted to Buddhism, together with several hundred thousand followers, as he saw no hope of abolishing caste discrimination within Hinduism. In contrast to Gandhi, conversion was thus, for him, a strategic move to improve the situation of Dalits.

\section{Conclusion}

To leave Hinduism is a complicated affair in several respects. The first difficulty is the fuzziness of the notion of "Hinduism," which means that one can, in principle, worship any divine being, hold widely divergent beliefs regarding the makeup of the universe, and even practise radically different rituals but still remain under the generous canopy of Hinduism. Both in the Indian constitution and within some forms of Hindu nationalism, Hindu has an even broader meaning than Hinduism, encompassing all major religions originating in the Indian subcontinent. Nevertheless, this notion excludes Christianity and Islam, two religious traditions that have a long history and deep roots in the Indian subcontinent. This is of importance, as Indian personal law is divided along Hindu, Christian and Muslim lines.

A further complication is that Hinduism entails not only a religious identity in the sense of membership in a religious organisation but also strong forms of traditional social belonging connected to caste. To leave just the "religion" and not one's social role and identity is therefore difficult. The underlying idea common both to Mahatma Gandhi and to Hindu nationalists was that conversions are unnatural and mostly the result of material inducements or fraud. Religion is something into which one is born, not something one chooses.

This ethno-nationalist understanding of Hinduism is operative in the decision of many Indian states to introduce religious freedom bills that control 
and restrict conversions. In this way, the territorially, ethnically, and culturally bounded nature of Hinduism is marked. This question is different for Hindus who live in a diaspora in which the original social and cultural environments of Hindu traditions are weaker and laws against conversion are mostly absent. Hindu individuals and communities continuously face the choice of trying, as much as possible, to uphold what is perceived as the original cultural and ethnic character of the religion through only marrying within the group, keeping up the Indian language in question, keeping traditional choices of food and other cultural practices; in this way, they affirm the view of Hinduism as a religion that one cannot leave without leaving one's "natural" social belonging. Alternatively, one can try to develop a form of Hinduism that is separate from Hinduism's original Indian cultural matrix, thus moving towards a universal religion that is not dependent on "common blood" or the sacred nature of the territory and culture of the Indian subcontinent.

A third option is that suggested by Ambedkar; he denounced Hinduism for its entangled nature of social, cultural and religious aspects (its integral character). Ambedkar decided that it was almost impossible to reform Hinduism and that the only way, at least for the marginalised, to achieve social equality and spiritual liberation, was to leave. Therefore, the issue of leaving Hinduism warrants closer inspection that is composed of several parts: leaving being Hindu, leaving India, and leaving Hinduism. The difficult question is what Hinduism would be after having ceased to be Hindu and having left India behind.

\section{References}

Ahuja, A. 2015. "Crossing Caste Boundaries in the Modern Indian Marriage Market." Studies in Comparative International Development. 51:3, 365-387.

Aklujkar, A. 2014. "History and Doxography of the Philosophical Schools." In J. Ganeri ed., The Oxford Handbook of Indian Philosophy. Oxford: Oxford University Press, $32-55$.

Ambedkar, B.R. 2014 [1936]. Annihilation of Caste: The Annotated Critical Edition, B.R. Ambedkar with an Introduction, "The Doctor and the Saint." Arundhati Roy, ed., London \& New York: Verso.

Barua, A. 2015. Debating "Conversion" in Hinduism and Christianity. London: Routledge. Bauman, C.M. 2014. Pentecostals, proselytization, and Anti-Christian Violence in Contemporary India. New York: Oxford University Press.

Bhandarkar, D.R. 1957. "Asoka and his Successors." In K.A. Nilakanta Sastri ed., A Comprehensive History of India, Vol. Two, The Mauryas and Satavahanas, 325 B.C.-A.D. 30o. Bombay: Orient Longmans, 20-49. 
Berg, T.V., and F. Kniss. 2008. "ISKCON and Immigrants: The Rise, Decline, and Rise Again of a New Religious Movement." The Sociological Quarterly. 49:1, 79-104.

Bronkhorst, J. 2017. "Brahmanism: its Place in Ancient Indian Society." Contributions to Indian Sociology. 51:3, 361-369.

Coward, H. 2003. Gandhi, Ambedkar, and Untouchability. In H. Coward ed., Indian Critiques of Gandhi. Albany, NY: State University of New York Press, 41-66.

Dabholkar, D. 1992. "Mahatma Gandhi: A Living Embodiment of Hindu-Christian Dialogue." Journal of Hindu-Christian Studies. 5:1, 23-28.

Datta, N. 2012. "Dayananda Saraswati." In K. Jacobsen, H. Basu, A. Malinar and V. Narayanan eds, Brill's Encyclopedia of Hinduism. Leiden: Brill.

Dwivedi, O.P. 2012. "Hinduism: Historical Setting." In M.D. Palmer and S.M. Burgess eds, The Wiley-Blackwell Companion to Religion and Social Justice. Chichester West Sussex: Wiley-Blackwell, 110-123.

Fernandes, L. 2011. "Unsettled Territories: State, Civil Society, and the Politics of Religious Conversion in India." Politics and Religion. 4, 108-135.

Gelberg, S.J. 1998. "On Leaving ISKCON." Krishna Today. At http://minet.org/www .trancenet.net/krishna/opinion/gelberg.shtml. Accessed 11/28/2017.

Ghosh, P.S. 2009. "Politics of Personal Law in India: The Hindu-Muslim Dichotomy." South Asia Research. 29:1, 1-17.

Gottschalk, P. 2012. Religion, Science, and Empire: Classifying Hinduism and Islam in British India. Oxford: Oxford University Press.

Hackett, C. 2015. "By 2050, India to have world's largest populations of Hindus and Muslims." Pew Research Center. At http://www.pewresearch.org/fact-tank/2015/04/ 21/by-2050-india-to-have-worlds-largest-populations-of-hindus-and-muslims. Accessed 11/28/2017.

Jacobsen, K.A. 2004. "Establishing Ritual Space in the Hindu Diaspora in Norway." In K.A. Jacobsen ed., South Asians in the Diaspora: Histories and Religious Traditions. Leiden: Brill, 134-148.

Jacobsen, K.A. 2013. "Introduction to Brill's Encyclopedia of Hinduism." In K.A. Jacobsen, H. Basu, A. Malinar, and V. Narayanan eds, Brill's Encyclopedia of Hinduism. Leiden: Brill.

Jaffrelot, C. 2011a. "India: The Politics of (Re)Conversion to Hinduism of Christian Aboriginals." In P. Michel and E. Pace eds, Annual Review of the Sociology of Religion, Volume 2, Religion and Politics. Leiden: Brill, 197-215.

Jaffrelot, C. 2011b. "Militant Hindus and the Conversion Issue (1885-199o)." In C. Jaffrelot ed., Religion, Caste and Politics in India. London: Hurst \& Company, 144-169.

Jenkins, L.D. 2008. "Legal Limits on Religious Conversion in India." Law and Contemporary Problems. 71, 109-126.

Jodhka, S. 2012. Caste. Oxford: Oxford University Press.

Kulke, H., and D. Rothermund. 1998 [1986]. A History of India. London: Routledge. 
Lorenzen, D. 2006. Who Invented Hinduism? Essays on Religion in History. New Delhi: Yoda Press.

Luchesi, B. 2004. "Tamil Hindu Places of Worship in Germany." In K.A. Jacobsen ed., South Asians in the Diaspora: Histories and Religious Traditions. Leiden: Brill, 116-133.

Mishral, I. 2015. "Minorities commission says Agra Muslims had 'not converted" Times of India. At https://timesofindia.indiatimes.com/city/agra/Minorities-commission -says-Agra-Muslims-had-not-converted/articleshow/46099720.cms. Accessed 6/19/ 2017.

Misra, A. 2011. "The Missionary Position: Christianity and Politics of Religious Conversion in India." Nationalism and Ethnic Politics. 17:4, 361-381.

Olivelle, P. 2005. “The Renouncer Tradition." In G. Flood ed., The Blackwell Companion to Hinduism. Malden, MA: Blackwell Publishing, 271-287.

Phillips, B.T. and Kelner, S. 2006. "Reconceptualizing Religious Change: Ethno-Apostasy and Change in Religion Among American Jews." Sociology of Religion. 67:4, 507-524.

Richards, I.D. 2004. "The Perception of Violence: Conversion in Post-Independence India." MA. University of Calgary. At https://search-proquest-com.ezproxy.ub.gu.se/ docview/305029526. Accessed 7/3/2019.

Richards, I.D. 2017. "Poles Apart: The Debates on Religious Conversion in PostIndependence India." PhD. University of Toronto, Canada. At https://search-pro quest-com.ezproxy.ub.gu.se/docview/1916538796. Accessed 7/3/2019.

Robinson, R. 2003. Christians of India. New Delhi: Sage Publications.

Robinson, R. 2007b. "Modes of Conversion to Islam." In R. Robinson and S. Clarke eds, Religious Conversion in India: Modes, Motivations, and Meanings. Oxford: Oxford University Press, 23-28.

Samarendra, P. 2016. "Religion and Scheduled Caste Status." Economic \& Political Weekly. 51: 31, 13-16.

Sarkar, S. 2007. "Christian Conversions, Hindutva, and Secularism." In A.D. Needham and R.S. Rajan eds, The Crisis of Secularism in India. Durham: Duke Univeristy Press, $35^{6}-367$.

Savarkar, 1969 [1923]. Hindutva: Who is a Hindu? Bombay: Veer Savarkar Prakashan.

Sharma, A. 2014. "Hinduism and Conversion." In L.R. Rambo and C.E. Farhadian eds, The Oxford Handbook of Religious Conversion. Oxford: Oxford University Press, 429-443.

Sikand, Y. 2007. "Arya Shuddhi and Muslim Tabligh: Muslim reactions to Arya Samaj Proselytization (1923-30)." In R. Robinson and S. Clarke eds, Religious Conversion in India: Modes, Motivations, and Meanings. Oxford: Oxford University Press, 99-118.

Spinner-Halev, J. 2005. "Hinduism, Christianity, and Liberal Religious Toleration." Political Theory. 33:1, 28-57.

Stephens, R.J. 2007. "Sites of Conflict in the Indian Secular State: Secularism, Caste and Religious Conversion." Journal of Church and State. 49:2, 251-276. 
Talbot, I. 2008. “The 1947 Partition of India." In D. Stone ed., The Historiography of Genocide. Houndmills, Basingstoke: Palgrave Macmillan, 420-437.

Tartakov, G. 2007. "B.R. Ambedkar and the Navayana Diksha." In R. Robinson and S. Clarke eds, Religious Conversion in India: Modes, Motivations, and Meanings. Oxford: Oxford University Press, 192-215.

Vandevelde, I. 2011. "Reconversion to Hinduism: A Hindu Nationalist Reaction Against Conversion to Christianity and Islam." South Asia: Journal of South Asian Studies. 24:1, 31-50.

Verma, V. 2017. "Secularism in India." In P. Zuckerman and J.R. Stock eds, The Oxford Handbook of Secularism. Oxford University Press.

Vertovec, S. 2000. The Hindu Diaspora: Comparative Patterns. London: Routledge.

Waughray, Annapurna. 2010. "Caste Discrimination and Minority Rights: The Case of India's Dalits." International Journal on Minority and Group Rights. 17, 327-353.

Zelliot, E. 2015. "Ambedkar's Life and his Navayana Buddhism." In K.A. Jacobsen ed., Routledge Handbook of Contemporary India. London: Routledge, 361-370. 